\title{
Research on Formulating Work-integrated Learning Talent Training Program of Higher Vocational Education*
}

\author{
Xianbin Li ${ }^{1}$, Dongjie Bao ${ }^{2}$, Pengfei Jia ${ }^{1}$, Xuedong Wang ${ }^{1}$ and Xuefeng Yuan $^{2}$ \\ ${ }^{1}$ Academic Service Section, Xingtai Polytechnic College, Hebei Province 054035, China \\ ${ }^{2}$ Department of Civil Engineering and Architecture, Xingtai Polytechnic College, Hebei Province 054035, China \\ bdjer330@163.com, 13513199314@163.com
}

\begin{abstract}
Higher vocational education program is guidance document that is to determine its educational objectives and guarantee the quality of education. In this paper, we defined the connotation on core concepts of talent training program and workintegrated learning, studied the elements on formulating talent training program, and give the ideas and basic requirements. All those provide a reference to further deepen the vocational education program.

Index Terms - talent training program, higher vocational education, work-integrated learning
\end{abstract}

\section{Introduction}

In 2006, the Ministry of Education, Ministry of Finance jointly issued "on the Implementation of the National Model of Higher Vocational Colleges Construction Plans to Accelerate the Reform of Higher Occupation Education and Development." (Higher education [2006]14, PR China).They clearly request running mechanism reform, innovating the mode of talent cultivation, reforming the curriculum system and teaching content, and integrating the key occupation ability training into the teaching system. The learning of theoretical knowledge, the practical ability and the overall quality should be closely joined together, so as to improve the employment ability of students, to speed up regional and industry high talents training. During the same year, the Ministry of Education in the "Several Opinions on Comprehensively Improving the Teaching Quality in the Higher Vocational Education" (Higher education [2006]16, PR China) proposed promoting the work-integrated learning research, the reform of talent training program, the combination of productive labor and social practice mode of learning, which take the work-integrated learning as the important starting point for higher vocational education reform.

The fundamental purpose of "the National Model of Higher Vocational Colleges Construction Plan" is to build a more mature system of talents training system with Chinese characteristics. As a type of higher education, the higher vocational education shoulders the mission of training highly skilled personnel for production, construction, service and management. The maximum difference between the higher vocational education and the current undergraduate education lies in its clear occupation value orientation and the practice, openness and occupation-orientation in the teaching process.
Thus, the teaching reform and construction of higher vocational education are bound to have a professional construction, and to create a mode as the main line and general principles. "Employment-oriented, work-integrated" is the focus of higher vocational education reform. The key and difficulty with "Employment-oriented, work-integrated" is the design of talent training program, which is the key to the success of teaching reform.

\section{The Definition of Core Concepts}

\section{A. Work-integrated learning}

Work-integrated leaning means the combination of educational activities and production activities, of which contains at least two meanings. One is the combination of education and productive labor that is theoretical knowledge combined with practice, with emphasis on the process. The other is the department of education combined with the productive labor units, which is the combination with the Department of education and industry, or colleges and enterprise cooperation, emphasizing the combination of object. The main purpose of this education mode is to improve students' comprehensive quality and employment competition ability, and improve the ability to adapt to the social needs of school education. For the combination of learning and working mode of education, different countries have their habitual names. For example, in the United States it is called the "cooperative education" or "work combined with study", known in the UK as "sandwich education". In China, it is known as the "work-integrated learning" or "work-study", "work and study alternation".

\section{B. Talent training program}

The talent training program is specific and practical objectives and specifications of talents training, and is the center link of professional training objectives and specifications. It is also the blueprint of the implementation of talent cultivation. The talent training program structure includes training objectives, training requirements, curriculum setting, scheduling, curriculum standards, teaching staff, equipment and mechanism system. The training objectives and training specifications are about "what kind of people to cultivate", while the curriculum is to explain "how to cultivate people".

\footnotetext{
* This work is supported by Higher Education Reform Fund of Hebei Province, PR China \# 103071 to Xianbin Li.
} 


\section{Elements Research of Talent Training Program}

Studies showed there must be three basic elements to establish scientific and reasonable talent training program. The first is to select the main line for the construction of training program. The second is to select courses based on different disciplines. The third is to select appropriate technology courses and make specific amendments on teaching plans.

\section{A. Building the Main Line of a Training Program}

The main line of training program is also the main line of the curricular system. The main line of training program is designed to enable students to form reasonable structure of knowledge, ability, and quality. The main line selection will lead to different training results. The structure model of professional training programs refers to both curriculum structures and also structural model of teaching plan, which means the kind of vertical and horizontal linkages and combination of various courses. It is an important issue building in a training program. Technical route selection should be based on professional training objectives and specifications, follow certain principles, and implement certain aspects.
Construction of higher vocational talent training program should be based on "three in one" as the main line, that is, it should take "integrate knowledge transfer, capacity building and quality improvement" as the main line of building professional development program. Specifically, it should be based on the QKC-S (Professional Quality, Basic Knowledge, Professional Competence, and Systematization) concept in higher vocational talent training program development and curriculum development. It takes the growth experience in the course of professional work as a basis for designing curriculum system. It systematically focus on training students' comprehensive professional ability, while emphasizing the systematization of training students' professional quality and cultivating students' systematic basic knowledge.

\section{B. The Curriculum Structure}

Typical work is based on the main job task analysis, theoretical knowledge, and professional skills of professional quality comb system in three ways. According to points of universality, transition and personality for quality, knowledge and competence decomposition and consolidation, QKC-S construction of curriculum system structure and its model are formed, as shown in Fig. 1.

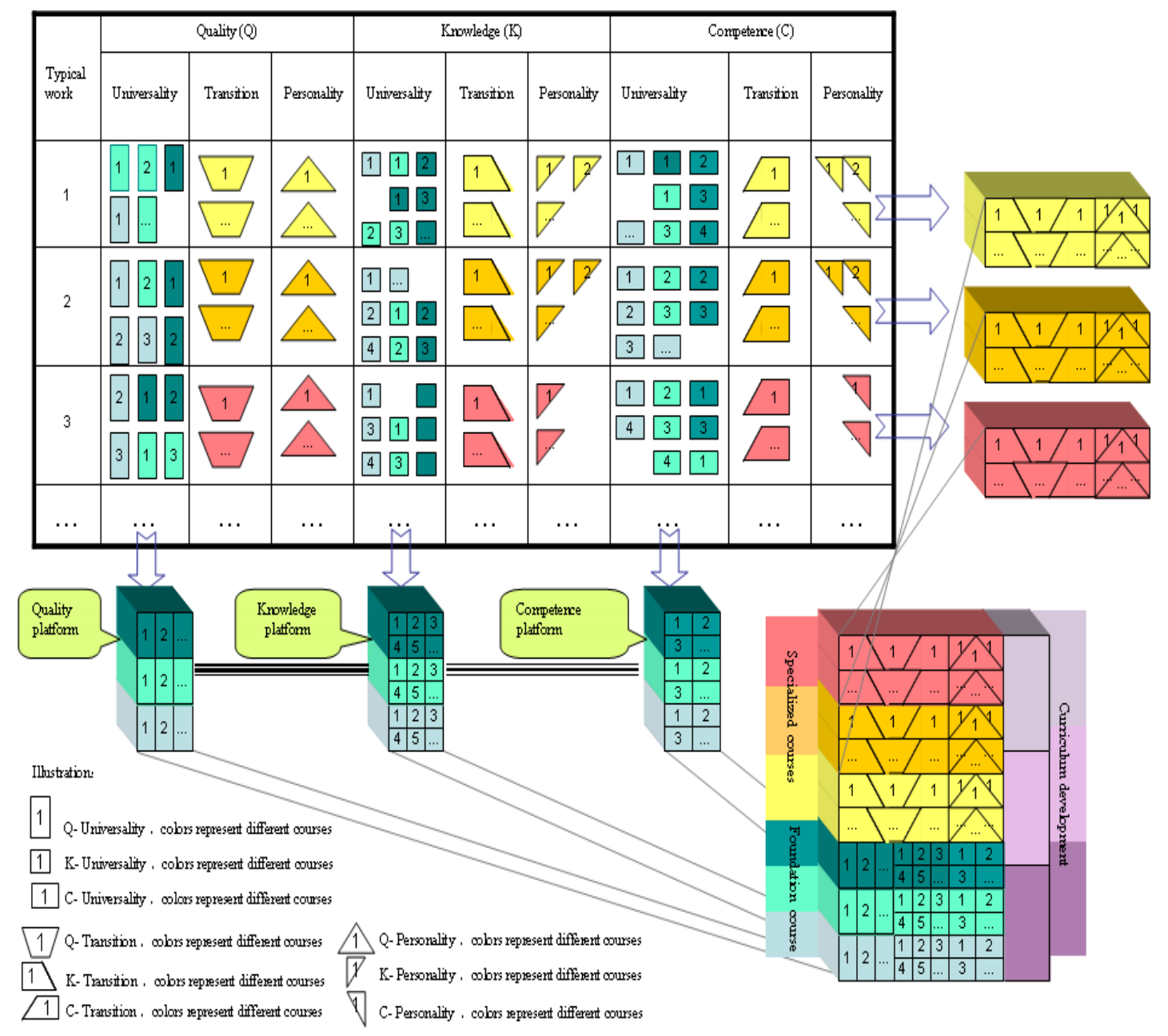

Fig. 1 QKC-S construction of curriculum system structure and its model 


\section{The Technological Line of Teaching Plan Revision}

There are six key factors affecting the quality of talents, that is, a solid one top post of course, productive practice and training, internships, faculty, teaching and learning conditions, mechanisms and systems. The six elements have inherent logical relationship, as shown in Table 1 .

Table 1 "Three Longitudinal and Three Transverse Model " of System Structure and Logical Relationships among the Six Elements of the Matrix Relation

\begin{tabular}{|l|l|l|l|}
\hline & Teaching team & Teaching conditions & $\begin{array}{l}\text { Mechanism } \\
\text { and system }\end{array}$ \\
\hline $\begin{array}{l}\text { Integration of } \\
\text { theory and practice } \\
\text { of curriculum }\end{array}$ & $\begin{array}{l}\text { Full-time and } \\
\text { part-time }\end{array}$ & $\begin{array}{l}\text { Integration of theory } \\
\text { and practice } \\
\text { professional classroom }\end{array}$ & $\begin{array}{l}\text { Process } \\
\text { management }\end{array}$ \\
\hline Productive training & $\begin{array}{l}\text { Full-time and } \\
\text { part-time }\end{array}$ & $\begin{array}{l}\text { Production type } \\
\text { teaching workshop }\end{array}$ & $\begin{array}{l}\text { The operation } \\
\text { of enterprises, } \\
\text { dual identity }\end{array}$ \\
\hline Internship & $\begin{array}{l}\text { Part-time and } \\
\text { full-time }\end{array}$ & $\begin{array}{l}\text { The integration of } \\
\text { engineering } \\
\text { cooperation enterprise } \\
\text { learning position }\end{array}$ & $\begin{array}{l}\text { Flexible } \\
\text { management, } \\
\text { staff } \\
\text { management }\end{array}$ \\
\hline
\end{tabular}

The "Three Longitudinal and Three Transverse Model" is the basis of the logical relations among the six elements of the matrix, based on requirements of talent training process and enterprise implementation. A detailed revision of teaching plan is based on the professional reality, bringing it more in line with the requirements of the talent training and more practical; so as to improve the relevance and applicability of talent training, upgrade the quality of talents.

\section{Basic Requirements for Formulating Work-integrated Talent Training Program}

\section{A. Precisely Positioning Professional Training Objectives}

We should carry out full of industry research and analyze in-depth professional industrial base, development-orientation and job characteristics. Taking changes in market demand as the direction, we identify the professional position, which fully reflects the characteristics of higher vocational education.

\section{B. Constructing Course System of Working Process Systematization}

We should build courses system based on work process thought and release the control of discipline courses of thought. Training students integrated career capacity and promoting students career development as target, we carry out overall of career analysis, and arrange professional positioning of career growth course and typical work task, which is the basis for transformation into courses. "From completing simple work task to completing complex work task" of capacity development process as the basis for courses sort, we provide students learning opportunities of full work process, and achieve progressive realization of the learner to a worker role.

\section{Organizing Course Content " on the Basis of Working "}

The core element of the course is "how to work". We take effective occupational task analysis, make clear work tasks of the course corresponds to professional research, such as "objects", "tools", "method", "organization of work" and "work requirements". We comb work process knowledge, and make clear learning content combined with teaching requires.

\section{Selecting the Appropriate Carrier Design Teaching}

According to the reality series, we design learning tasks to meet the professional development, from lower ability students stage an orderly, efficient strip into a higher stage of development. The carrier selection should take into account typical, coverage, feasible, activities design to meet the student's ability level and teaching needs.

\section{E. Referring to the Requirements for Professional Skills Identification}

We select a high degree of social recognition, well for student employment vocational qualifications. After specific analysis of their content and requirements, we optimize the curriculum system and teaching content, which enable students to obtain qualifications and at the same time to obtain the appropriate professional qualification certificate successfully.

F. Strengthening Cooperation between Schools and Enterprises to Increase Openness and Systemic Training Programs

Through cooperation between schools and enterprises, we make enterprises full participation in the development and implementation of training programs, which increase the practicality, openness and profession of teaching process. We gradually increase the proportion of outside top-post practice productive practice and training. Following the law of progressive increase, practice course, productive training and post attachment system should be arranged systematically at all stages.

\section{G. Students ' Comprehensive and Sustainable Development}

We insist moral first in education. We put Socialist core value system, and modern enterprise excellent culture concept into full talent training process, which enhance students' ethics and career spirit training. We advocate teaching of students for main, teachers for led, training students' self-study capacity, improving social adaptation capacity, and educating students with lifelong learning concept. Our goal is to train students' integrity quality, dedicated spirit, and responsibility consciousness, and compliance consciousness, that is, full development of high-end skills specifically talents.

\section{References}

[1] Dongmei Zeng, Hongjian Xi and Guoxun Huang, "On the establishment of professional personnel cultivation project," Research On Education Tsinghua University, vol. 23, no. 5, pp. 98-101, October 2002.

[2] Caiqin Liu and Qinghua Liu, "Exploration of the personnel cultivation mode on work-integrated learning in higher vocational educationBased on the demonstration-school project of Xingtai Polytechnic College," Journal of Higher Education, vol. 31, no. 1, pp.64-67, January 2010.

[3] Zhiqun Zhao, New Learning Concept of the Technical and Vocational Education and Training, Beijing: Science Press, 2003, pp. 69-97.

[4] Dayuan Jiang, New Theory on the Study of Vocational Education, Beijing: Educational Science Press, 2007, pp. 164-195. 